\title{
Le 'fonti' delle connessioni
}

\author{
Mara Gallo
}

Abstract

Ogni città, nelle sue specificità, è un sistema di connessioni; un sistema di eventi fisicamente o virtualmente interconnessi. Tra le reti di connessioni nella storia delle civiltà umane, l'acqua svolge un ruolo fondamentale. L'acqua, elemento connettivo, è un bene primario per la vita, la cui capillare presenza e capacità di percorrere luoghi ne fanno una perfetta via di trasporto e di comunicazione. Quando l'uso dell'acqua non è più finalizzato solo al sostentamento, diventa segno estetico ed espressivo. Le fontane sono un elemento costruttivo creativo: animano le piazze e decorano la scena urbana dando un sontuoso spettacolo di sé, dell'epoca, e del potere che le ha commissionate. Nei secoli, acquistano una grande valenza architettonica e scultorea; diventano punto focale dell'organizzazione degli ambienti urbani coinvolgendo e determinando lo spazio circostante. La città di Salerno, affacciata sulla costa sudorientale del marTirreno, possiede una fortissima connessione con l'acqua nelle sue molte forme. Si propone dunque un percorso alla scoperta delle principali fontane del suo centro storico, partendo dall'alto e scendendo a valle, seguendo le curve di livello della città. Suddetto percorso mette in connessione le diverse fontane accompagnando il visitatore in un viaggio tra storia e arte. In un periodo in cui le restrizioni dovute alla pandemia di COVID- 19 rendono complicato spostasi, il disegno e le rappresentazioni 3D liberano il cammino verso la conoscenza e permettono di visitare le città e fruirne le bellezze senza che sia necessaria la presenza fisica.

Parole chiave

connessioni d'acqua, fontane, disegno, rilievo 3D, percorsi.

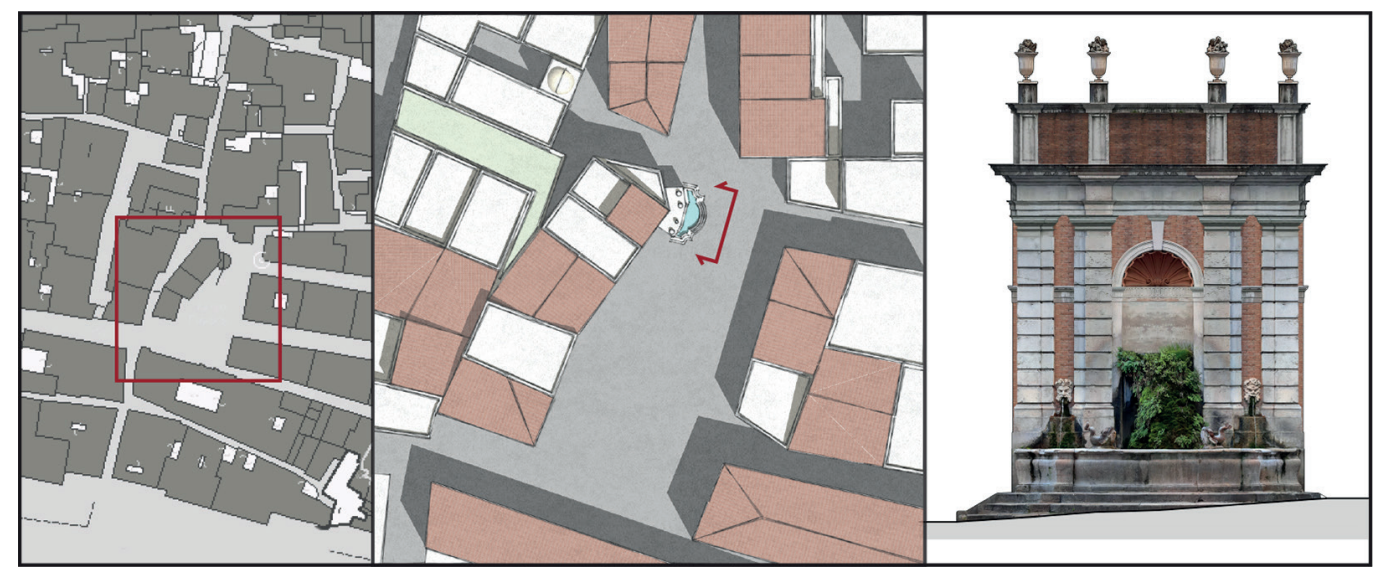




\section{Introduzione}

Ogni città nelle sue specificità, nelle sue trasformazioni e nelle sue mille declinazioni si offre allo sguardo di chi legge come un sistema ricco di connessioni, che nel tempo si è consolidato a partire da alcuni luoghi densi di significato nella sua memoria storica, in virtù delle attività che in esso si svolgevano.

Connessioni fisiche come la rete dei percorsi, ma anche connessioni intangibili che pongono in relazione, nell'ambito di tracciati invisibili, le architetture e le parti urbane, associandole per epoche storiche, per tipologie, per funzioni e definendo implicitamente un articolato sistema di luoghi, di ambiti che intorno ad essi gravitano e di percorsi che li collegano.

Rileggere una città attraverso l'analisi di questi luoghi significa predisporre una lettura critica, volta ad analizzare l'insieme, indagando il tessuto urbano come un sistema di eventi fisicamente o virtualmente interconnessi. Le città storiche, infatti, si sono sviluppate intorno ad alcuni invasi, ancor oggi fortemente radicati nella memoria collettiva, che hanno assunto nel tempo un ruolo culturale di più ampia portata.

In tale ambito di riflessioni, il presente studio intende indagare il ruolo di alcuni 'elementi' di arredo urbano quali le fontane con particolare riferimento alla città di Salerno e intese da un lato quali elementi volti a segnare un vuoto urbano attraverso la loro presenza e a consacrare il luogo in cui si collocano quale luogo dellincontro, dall'altro implicitamente a suggerire l'esistenza di una rete più ampia presente nella città stessa e che correla contesti analoghi.

Le fontane sono sorgenti di vita. Sono storie, sono intrecci, sono poli di attrazione e luogo di relazioni e l'acqua che da esse sgorga può essere intesa quale fattore generativo dell'uso dello spazio in cui la fontana stessa si colloca.

Sin dall'antichità l'acqua rappresenta uno dei principali elementi della vita. Popola il mito, la religione e la filosofia. Panta rei, tutto scorre, diceva Eraclito, non puoi entrare due volte nello stesso fiume. Grazie a ciò e dunque alla sua capacità di percorrere i luoghi e di essere via di comunicazione, popoli e civiltà diverse sono venuti in contatto. L'acqua non possiede una forma, ma si adatta a ciò che la contiene creando implicitamente connessioni e istituendo relazioni di tipo diverso.

\section{L’acqua e la città}

Un tempo le fontane rappresentavano il punto di incontro della vita pubblica ed è ben noto che prima della realizzazione delle reti idriche, venivano utilizzate dai residenti per l'approvvigionamento dell'acqua per il consumo quotidiano e per gli usi domestici.

Nei centri abitati più importanti, accanto all'utilità pratica, si è andata sviluppando parallelamente anche una sempre più articolata esigenza estetica. Le fontane sono diventate perciò nel tempo elementi di arredo urbano, abbellendo le piazze e le vie cittadine con statue, fregi e giochi d'acqua.

Con l'arrivo dell'acqua corrente nelle abitazioni le fontane hanno perso il loro scopo originario, ma restano comunque radicate nella memoria dei luoghi e, pur non avendo la stessa importanza che avevano al momento della loro realizzazione, hanno conservato un importante ruolo per il valore architettonico, artistico e decorativo e per essere parte integrante degli invasi urbani entro cui sono collocate e a cui conferiscono un forte valore identitario. Lo studio delle fontane non può pertanto prescindere dallo studio del contesto urbano in cui si collocano in quanto si tratta di 'episodi architettonici' che creano uno spazio. Sono elementi che segnano fortemente la forma, la vita e l'uso di parti urbane e hanno dunque un valore specifico rispetto al contesto in cui si collocano. Le fontane infatti instaurano un rapporto emotivo con gli abitanti della città, rapporto che nasce dal legame primordiale con un bene essenziale, ma anche dal riconoscimento del loro valore estetico.

Le fontane nei secoli acquistano una importante valenza architettonica e scultorea, assumendo il ruolo di elementi di arredo urbano, proponendosi come vere e proprie opere d'arte che conferiscono identità e riconoscibilità ai luoghi dove l'acqua diventa segno estetico ed espressivo, animando le piazze e decorando la scena urbana. 


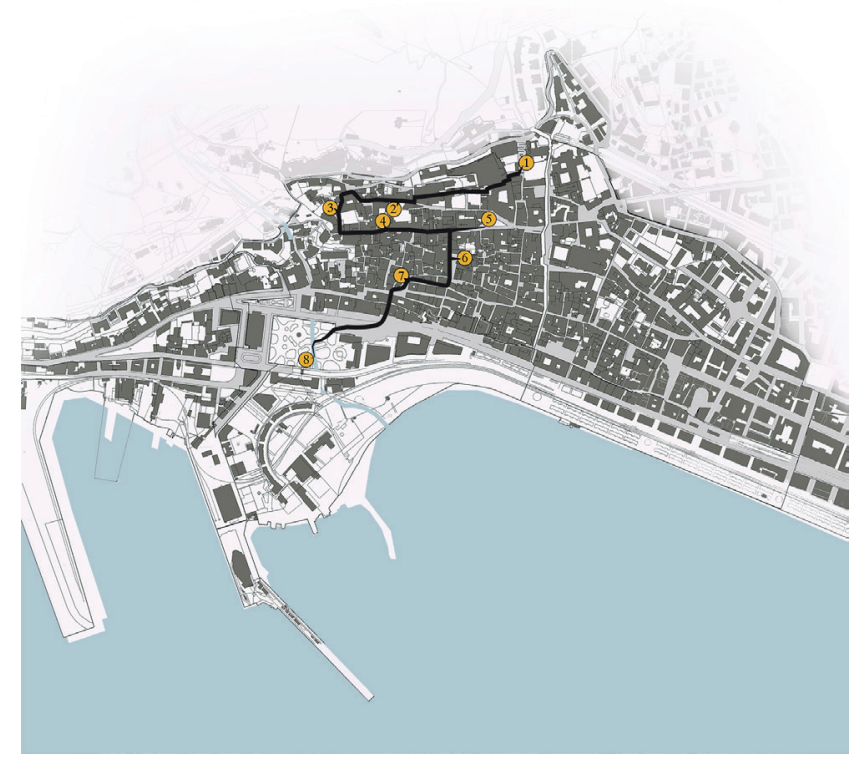

\section{L'acqua e la città di Salerno}

Alcune città hanno fatto della loro connessione con l'acqua la propria forza e la propria ricchezza. Salerno è una delle città che maggiormente racconta questa profonda relazione e che, per questo motivo, è stata scelta per raccontare lo stretto rapporto città-acqua. Salerno nasce e si sviluppa in una posizione incantevole, tra le colline, la piana, il golfo ed il mare. È ricca di contrasti, di colori e di vegetazione disparata a testimonianza della grande abbondanza di acqua e di rii che la percorrono. II paesaggio è mutato molto nei secoli, a causa dell'urbanizzazione e della richiesta abitativa, ma non ha mai perso la sua sinergia con il mare e con i monti sullo sfondo. [Vicidomini 2005]. Passeggiando tra i palazzi nobiliari, tra i conventi e le chiese si notano tantissimi dettagli che la impreziosiscono. Salerno riesce ad avere un suo carattere da qualunque punto la si guardi ed il castello Arechi, il Giardino della Minerva, il teatro Verdi e il mare fanno da fondale scenografico alla città.

Tantissimi sono i segni di un passato forte e radicato che è sopravvissuto all'urbanizzazione. Le costruzioni moderne e le contaminazioni non hanno perso il legame con la città antica e la sua storia è testimoniata dai numerosissimi reperti lungo le vie della città. Salerno si può definire una 'città d'acqua' poiché è un insediamento urbano di struttura complessa che mantiene una forte relazione con le acque nelle sue diverse forme. Le fontane sono un valore aggiunto che gioca un ruolo decisivo sulla fruizione visiva di diversi ambiti urbani [Bruttomesso 1993] (fig. I).

\section{Le fontane del centro storico di Salerno}

Lo studio ha inteso predisporre una catalogazione delle fontane di Salerno a partire da alcuni elementi costitutivi individuati nel disegno delle diverse esemplificazioni (fig. 2).

Viene proposto un percorso alla scoperta delle più importanti e significative fontane del centro storico partendo dall'alto e scendendo verso il mare, seguendo perciò l'andamento delle curve di livello e assecondando così lo scorrimento delle acque dei rii verso il mare. Questo 'percorso d'acqua' connette tra loro otto diverse fontane costruite in epoche diverse e di diversa fattura, ma tutte con un forte valore architettonico. Per questo sono state studiate, analizzate e mappate nelle loro principali caratteristiche (fig. 3).

Sono un punto focale di tutti gli ambienti in cui sono collocate e coinvolgono e determinano lo spazio in giochi di movimenti e di luce. 
Fig. 2. Percorso connettivo delle fontane del centro storico di Salerno.
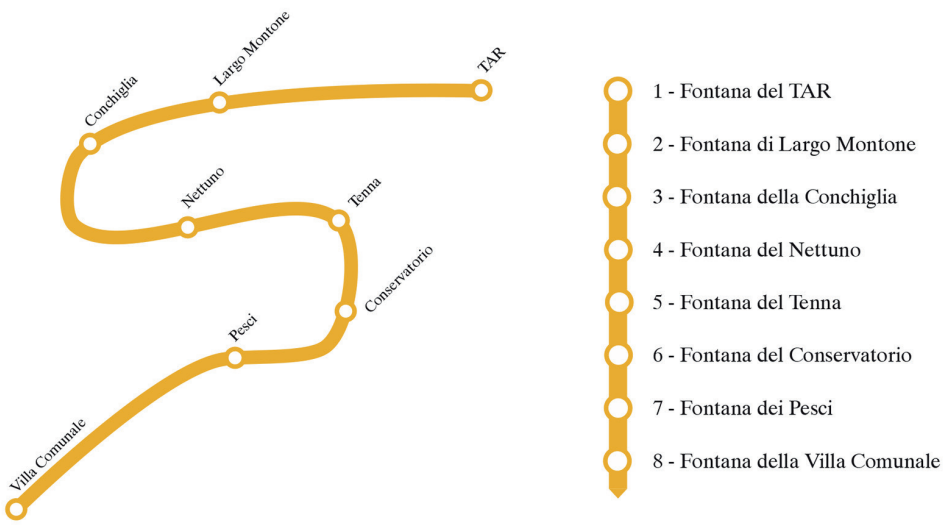

L'itinerario inizia con una fontana privata, collocata nel giardino del Tribunale Amministrativo Regionale (TAR), i numerosi rimaneggiamenti che ha subito hanno cambiato molto della fisionomia originaria della fontana e del contesto in cui si colloca. La fontana è semplice e armoniosa, racchiusa in una nicchia riquadrata da lesene. L'acqua si riversava attraverso delle piccole cascatelle in una conchiglia, per poi finire nella grande vasca polilobata. Tuttavia, nonostante dei restauri della fine del secolo scorso attualmente non è attiva (De Martino 1997). La fontana successiva è pubblica, attiva e si trova a Largo Montone. Databile intorno al XVII secolo è caratterizzata da un solo zampillo che fuoriesce dalla bocca di un mascherone con ghirlande. Proseguendo in quota incontriamo la Fontana della Conchiglia che è diventata Isimmagine-simbolo del giardino della Minerva, anche a livello internazionale. Fu creata nel Trecento, ma le monumentali dimensioni attuali sono frutto di un ampliamento e di restauri avvenuti nel Seicento ed nel Settecento. La fontana è attraversabile, ha una nicchia a forma di conchiglia ed è divisa in tre sezioni, con due paraste avvolgenti ai lati della vasca centrale.

Moltissimi palazzi del centro storico possedevano delle fontane private per assicurare l'approvvigionamento, ma anche per sottolineare il potere della famiglia e Palazzo Ruggi con la fontana del Nettuno all'interno del suo cortile privato ne è un importante esempio. Questa fontana è molto elaborata e dal sapore antico, ma è stata costruita nel $X X$ secolo e non è più attiva da molti anni.

Assecondando il pendio della strada si giunge in piazza Abate Conforti. Di fronte alla monumentale Chiesa della Santissima Addolorata insiste, sopra a tre gradoni, la fontana del Tenna. Sui bordi della vasca, disposti simmetricamente, si trovano quattro delfini dalla cui bocca zampilla l'acqua e al centro della vasca si trova una coppa di metallo, probabile fonte battesimale. Scendendo verso il mare si incontra il Conservatorio Ave Gratia Plena. All'interno del cortile, addossata al porticato, si trova una fontana di forte impatto visivo, composta da una nicchia affiancata da lesene con capitello. La costruzione culmina con un frontone spezzato e l'acqua si incontra allinterno di una vasca curvilinea.

Alcune fontane più semplici si alternano ad altre più complesse, ma spesso tra loro mantengono dei legami storici o stilistici. Sono molto frequenti alcuni elementi della poetica del periodo Rococò legata a grandi interpreti come Luigi Vanvitelli. Ė infatti attribuita a lui la successiva fontana, la celebre Fontana dei pesci situata a Largo Campo, e la sua mano è riconoscibile in una serie di scelte stilistiche ed elementi che si ripetono anche nelle altre fontane che ha progettato, dislocate in varie città d'Italia. Ha un fortissimo impatto perché si colloca in un Largo raggiungibile da molte strade importanti e dà forza agli scorci rendendoli potenti ed interessanti. Ė un simbolo fortemente iconico di tutto il centro storico e ha subito moltissime variazioni e rimaneggiamenti nei secoli. Si configura come una vasca bombata collocata su due gradini, la facciata ha forma trapezoidale ed è simmetrica. La nicchia centrale, con la conchiglia, è incorniciata da lesene bugnate che sorreggono una muratura sulla quale sono posti quattro vasi. Gli zampilli d'acqua sgorgano dalla conca marmorea centrale, dai pesci in metallo posti sul bordo della vasca e dai due mascheroni con ghirlande laterali. Tutti questi elementi artistici creano un piccolo angolo di storia e d'arte. Un angolo che lega tra loro le diverse fontane della città e la arricchiscono di bellezza. 

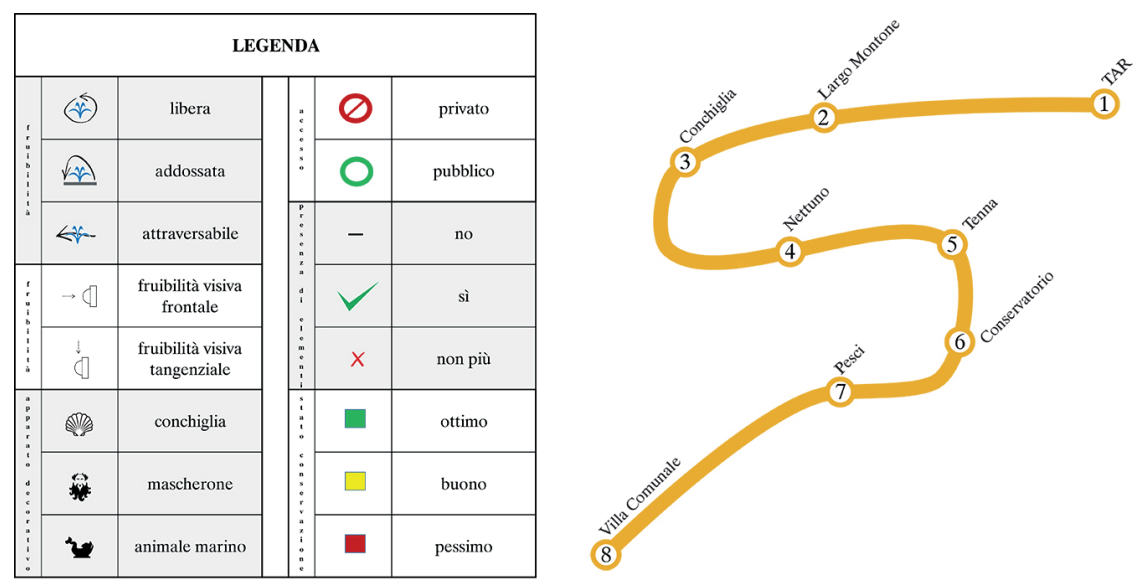

\begin{tabular}{|c|c|c|c|c|c|c|c|c|}
\hline numero & ) & 2 & 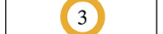 & ) & 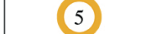 & & & 3) \\
\hline nome & Fontana del TAR & $\begin{array}{c}\text { Fontana di Largo } \\
\text { Montone }\end{array}$ & $\begin{array}{c}\text { Fotana della } \\
\text { Conchiglia }\end{array}$ & $\begin{array}{c}\text { Fontana del } \\
\text { Nettuno }\end{array}$ & Fontana del Tenna & $\begin{array}{c}\text { Fontana del } \\
\text { Conservatorio Ave } \\
\text { Gratia Plena }\end{array}$ & Fontana dei Pesci & Fontana del Tullio \\
\hline \multicolumn{9}{|l|}{ ortofoto prospetto } \\
\hline indirizzo & \begin{tabular}{|c|} 
Tribunale \\
Amministrativo \\
Regionale, Largo San \\
Tommaso D'Aquino
\end{tabular} & Largo Montone & $\begin{array}{c}\text { Giardino della } \\
\text { Minerva, Vicolo } \\
\text { Ferrante Sanseverino }\end{array}$ & $\begin{array}{l}\text { Palazzo Ruggi, Via } \\
\text { Tasso }\end{array}$ & Piazza Abate Conforti & Via dei Canali & Largo Campo & $\begin{array}{c}\text { Giardini della Villa } \\
\text { Comunale, Via } \\
\text { Gaetano D'Agostino }\end{array}$ \\
\hline periodo & XVII sec & XIV sec & XIV secolo & $\mathrm{XX} \sec$ & XVII sec & XVIII sec & XVII sec & XVIII \\
\hline ubicazione & corte interna & largo & terrazzo panoramico & corte interna & piazza & corte interna & largo & piazza \\
\hline impatto visivo & $\rightarrow \square$ & ¿ & $\rightarrow D$ & $\square$ & $\rightarrow O$ & $\rightarrow \subset$ & & $\rightarrow D^{2}=$ \\
\hline fruibilità & $\leftrightarrow$ & (*) & « & (x) & (ब) & (v) & x & (ब) \\
\hline $\begin{array}{l}\text { apparato } \\
\text { decorativo }\end{array}$ & 急 & 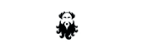 & 8 & - & 3 & - & 30 & - \\
\hline accesso & $\varnothing$ & 0 & $\varnothing$ & $\varnothing$ & 0 & $\varnothing$ & & 0 \\
\hline in attività & $x$ & & $\checkmark$ & $x$ & & & & \\
\hline $\begin{array}{c}\text { stato di } \\
\text { conservazione }\end{array}$ & $\square$ & $\square$ & $\square$ & $\mathbf{\square}$ & $\square$ & $\square$ & $\square$ & $\square$ \\
\hline $\begin{array}{l}\text { presenza partito } \\
\text { architettonico }\end{array}$ & $\checkmark$ & 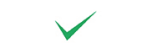 & $\checkmark$ & - & - & $V$ & & \\
\hline $\begin{array}{l}\text { presenza elementi } \\
\text { scultorei }\end{array}$ & - & - & - & $\checkmark$ & - & - & - & $x$ \\
\hline
\end{tabular}

L'itinerario si conclude scendendo sempre di più verso il mare e passando per laVilla Comunale. La Fontana del Tullio è in stile barocco, ed in un primo tempo ospitava una statua che poi è stata trafugata. Attualmente è attiva e arricchisce il collegamento paesaggistico tra il teatro Verdi, il mare e l'antica città storica e ha una grande importanza scenica, che valorizza e viene valorizzata dal contesto e l'insieme in cui si trova (fig. 4).

\section{Rilievo e disegno come mezzo espressivo di comunicazione}

Il crescente interesse verso la documentazione e la valorizzazione del patrimonio architettonico presente nei centri storici delle città, ha focalizzato l'attenzione sulle metodologie e sulle tecnologie utili ai fini del rilievo. La tecnologia diventa così al servizio della conoscenza e la rappresentazione diventa un mezzo utile per la comunicazione e la divulgazione.

Lo sviluppo tecnologico dei software di fotogrammetria hanno incentivato moltissime campagne di rilievo con la possibilità di creare modelli 3D e di indagare e navigare il modello 


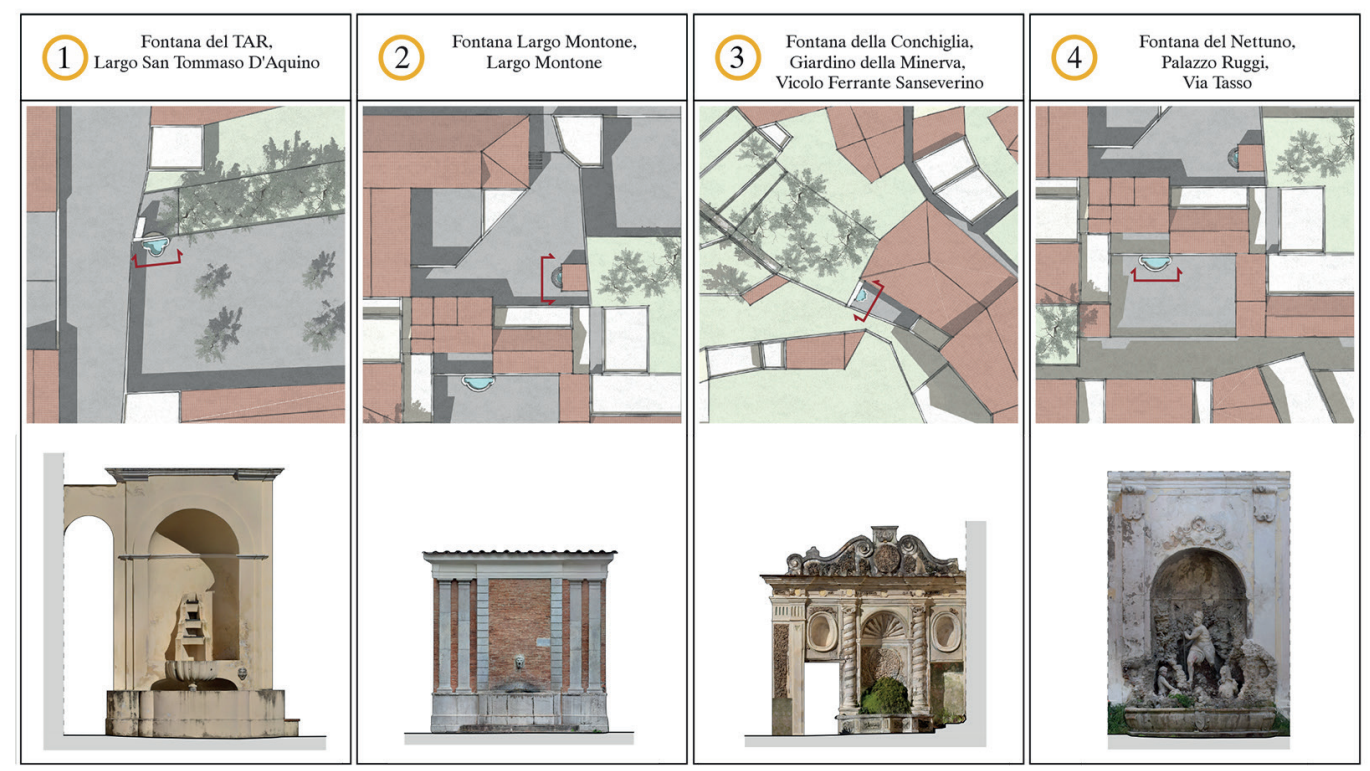

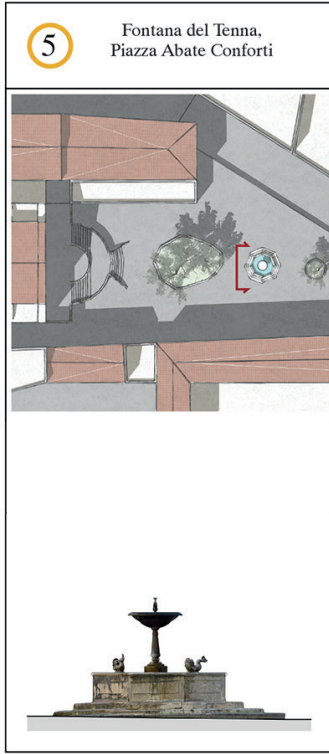

Fig. 4. Stralci planimetric del contesto e prospetti delle rispettive fontane.

Fig. 5. Passaggi del

post-processamento su Metashape della 'fontana dei pesci' di Salerno. Fontana del Conservatorio
Ave Gratia Plena,
Via dei Canali

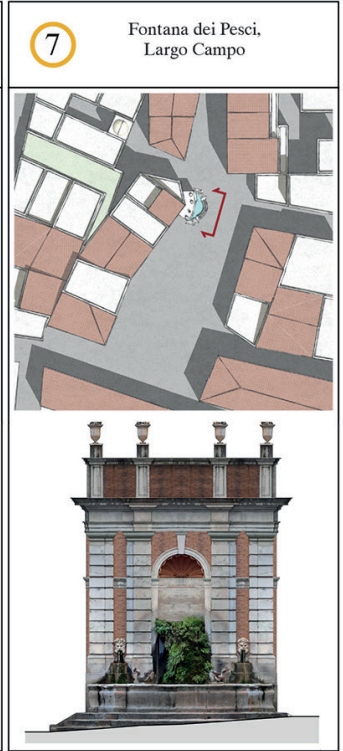

Orientamento e scala metrica pianta

(1)

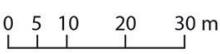

Fontana del Tullio,
Giardini della Villa Comunale,
Via Gaetano D'Agostino
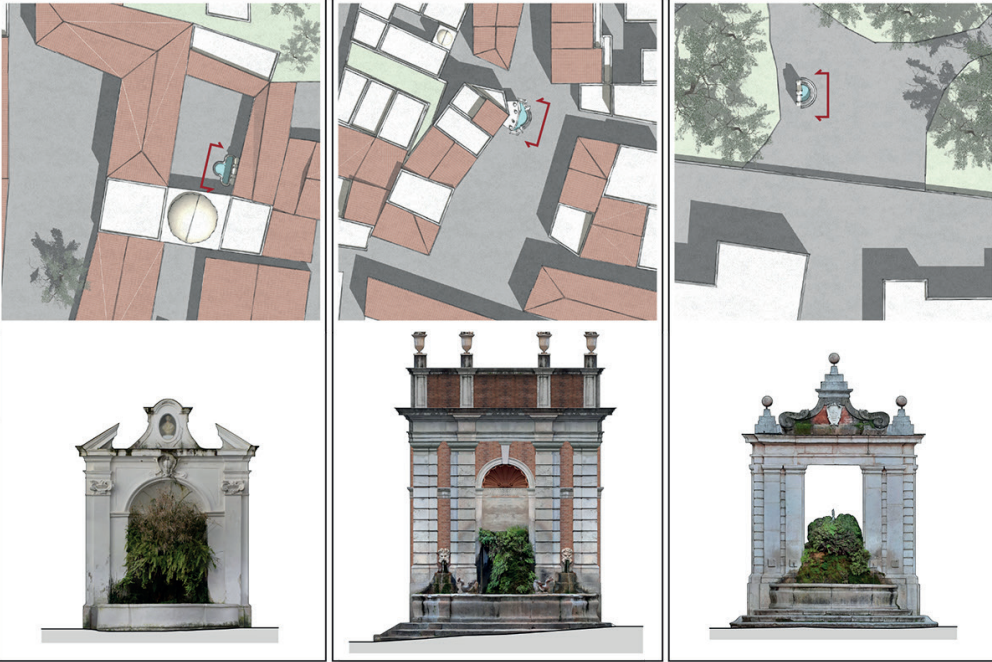

Scala metrica prospetto

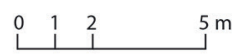

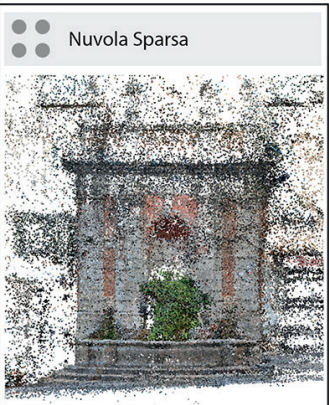
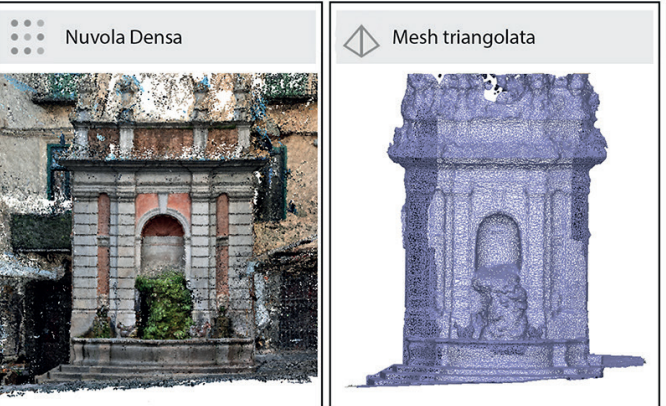

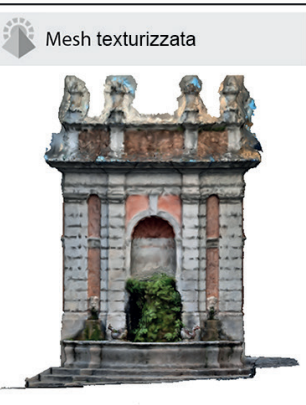



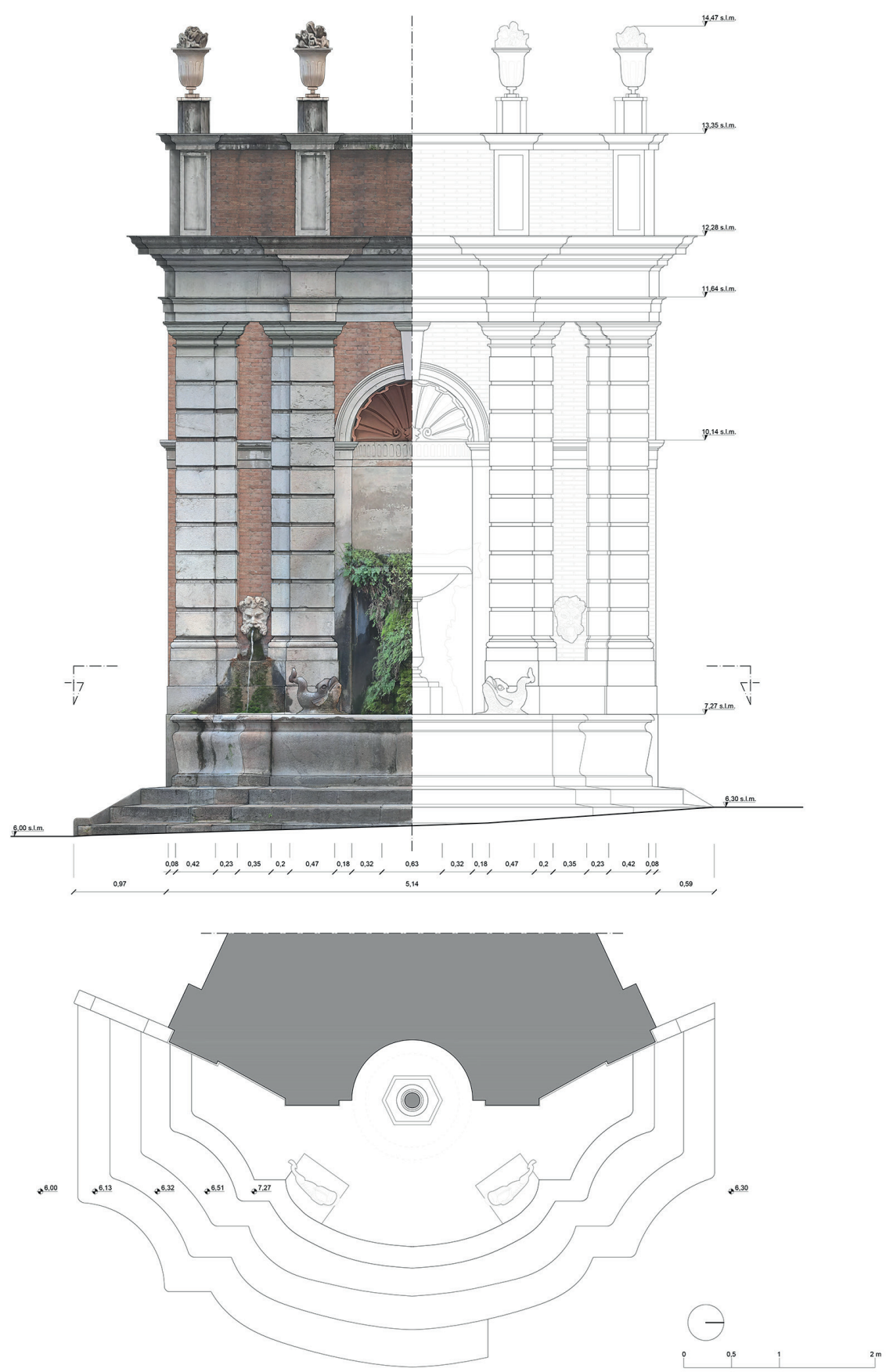

ottenuto esplorandone le specificità. La redazione di un buon rilievo architettonico è fondamentale e alla base di tutte le fasi della conoscenza di un'opera. È frutto di una iniziale comprensione critica dell'oggetto e tutte le fasi che seguono discendono da un processo di studio e di interpretazione in tutti i suoi aspetti costitutivi.

Attraverso il rilievo è possibile indagare le qualità di ogni manufatto nel reale, approfondendone i dati morfologici e dimensionali. Accanto a ciò la rappresentazione, nella sua attitudine a documentare, consente di rileggere tali relazioni ponendo le diverse esemplificazioni su un unico piano di rappresentazione dove ogni elemento acquista un nuovo significato nel confronto con gli altri e nella lettura sinottica che da esso ne deriva ed evidenza tutti i suoi valori intrinseci in relazione con il contesto urbano. II rilievo ed il disegno sono perciò sempre frutto di un processo critico e per questo è importante anche la scelta della metodologia più adatta a seconda del caso che si prende in esame. Per rilevare degli oggetti 'puntuali' come le fontane, 
è stato scelto il rilievo fotogrammetrico effettuato grazie ad una Fotocamera Reflex Nikon D3300. Le fotografie sono state scattate con prese ad assi paralleli e ad assi convergenti con una sovrapposizione almeno dell' $80 \%$ in verticale ed in orizzontale. L'allineamento dei diversi scatti in alta qualità (circa 350 scatti per ogni fontana) ha portato alla creazione di nuvole di punti prima sparse e poi dense. Ogni nuvola di punti è stata ripulita da tutti gli elementi di disturbo ed esterni all'oggetto e poi da questi è stata generata un mesh 3D (fig. 5).

Non conoscendo le coordinate assolute sono stati collocati dei marker sopra e vicino alle fontane. Allinterno del programma Metashape sono stati inseriti degli scale bar, overo le diverse distanze dei marker, ed è così stato possibile ottenere un modello scalato ma non geo-referenziato. L'errore per ogni fontana è di circa I-2 mm. Da ogni modello così ottenuto è stato possibile estrapolare delle orto-foto dei diversi fronti, utili all'elaborazione dei relativi prospetti e sezioni (fig. 6).

\section{Conclusioni}

Ogni città è la summa di singoli elementi, di storie e passaggi che si sono connessi ed evoluti tra loro. Non è possibile conoscere una città senza conoscerne i vari componenti e come questi si relazionano. Più l'opera sarà stata approfondita e studiata nella sua interezza, tanto maggiore sarà la quantità di informazioni che potrà acquisire l'osservatore. Ogni rilievo sarà quindi frutto di una scelta, di una operazione di sintesi critica ed ogni disegno, oltre ad essere preciso metricamente, metterà in evidenza le caratteristiche formali, il materiale lo stato di conservazione e le relazione dei diversi elementi.

II rilievo ed il disegno sono perciò degli strumenti essenziali per chi dovrà comprendere la natura e la storia di un certo manufatto o per chi, non potendolo vedere dal vero, ne verrà comunque a conoscenza e potrà fruire dell'architettura nella sua fisicità e complessità anche senza trovarsi direttamente sul luogo.

In questo periodo di pandemia, dove la segregazione ha ridotto la nostra possibilità di relazionarci con gli altri e di visitare città, le rappresentazioni 3D e la loro facilità di lettura sono il principale strumento per lo studio e lo sviluppo dell'innovazione. II tutto finalizzato al miglioramento della conoscenza, accessibilità e fruizione del patrimonio all'interno delle città.

\section{Riferimenti bibliografici}

AA.W. ( 1997). Fontane in città. $12^{a}$ Settimana dei beni culturali «l luoghi del patrimonio». Salerno: Menabò Comunicazione.

AA.W. (2005). Visitiamo la città. Ciclo di visite guidate 2004-2005. Salerno: Assessorato Al Turismo.

Bruttomesso R. (1993). Waterfronts. A new frontier for cities on water. Venezia: Centro internazionale città d'acqua.

De Luca L. (20I I). La fotomodellazione architettonica. Rilievo, modellazione, rappresentazione di edifici a partire da fotografie. Palermo: Flaccovio.

Docci M., Maestri D. (2009). Manuale di rilevamento architettonico e urbano. Milano: Laterza.

Falda G.B., De Rossi G.G., Venturini G.F. (1684). Le fontane di Roma nelle piazze, e luoghi publici della città, con li loro prospetti, come sono al presente. Roma: ETH-Bibliothek Zürich.

Ferrari L. (2004). Acqua che ri-corre nei luoghi. In Ri-Vista. Ricerche per la progettazione del paesaggio. n. I, vol. 2.

Lauretano M. (1997). Salerno e il suo centro storico. Salerno: Poligraf.

Remondino F. (20I I). Rilievo e modellazione 3D di siti e architetture complesse. In Disegnarecon. n.4, vol. 8, pp. 90-98.

Autore

Mara Gallo, Università degli Studi di Napoli Federico II, mara.gallo@unina.it

Per citare questo capitolo: Gallo Mara (202I). Le 'fonti' delle connessioni/The 'Sources' of Connections. In Arena A., Arena M., Mediati D., Raffa P. (a cura di). Connettere. Un disegno per annodare e tessere. Linguaggi Distanze Tecnologie. Atti del $42^{\circ}$ Convegno Internazionale dei Docenti delle Discipline della Rappresentazione/Connecting. Drawing for weaving relationship. Languages Distances Technologies. Proceedings of the 42th International Conference of Representation Disciplines Teachers. Milano: FrancoAngeli, pp. 2337-2352. 


\title{
The 'Sources' of Connections
}

\author{
Mara Gallo
}

\section{Abstract}

Every city, in its specificities, is a system of connections; a system of physically or virtually interconnected events. Among the networks of connections in the history of human civilizations, water plays a fundamental role. Water, a connective element, is a primary commodity for life, whose capillary presence and ability to traverse places make it a perfect transport and communication route. When the use of water is no longer just for sustenance, it becomes an aesthetic and expressive sign. Fountains are a creative constructive element: they enliven squares and adorn the urban scene, giving a sumptuous spectacle of themselves, of the era, and of the power that commissioned them. Over the centuries, they acquired great architectural and sculptural value; they became a focal point in the organization of urban environments, engaging and determining the surrounding space. The city of Salerno, on the south-east coast of the Tyrrhenian Sea, has a very strong connection with water in its many forms. We therefore propose a route to discover the main fountains in the historic center, starting from the top and descending to the valley, following the contour lines of the city. This route connects the different fountains and takes the visitor on a journey through history and art. At a time when restrictions due to the COVID-19 pandemic make it difficult to get around, drawing and 3D representations free up the path to knowledge and make it possible to visit cities and enjoy their beauty without the need for physical presence.

Keywords

water connections, fountains, drawing, 3D survey, paths.

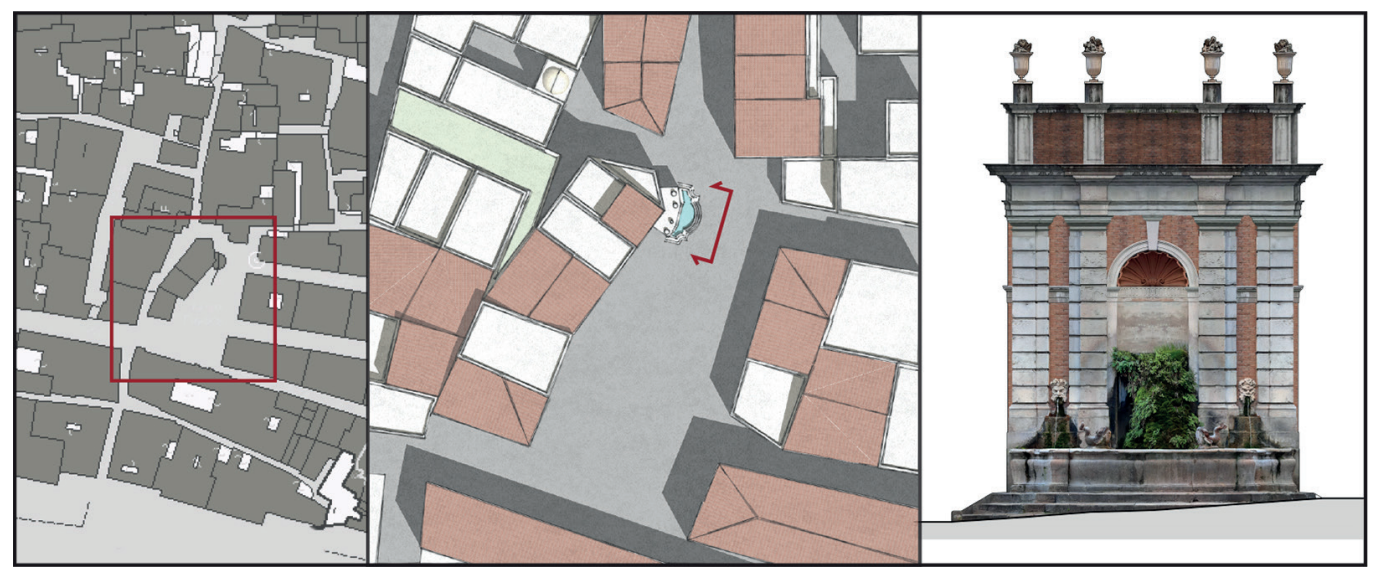




\section{Introduction}

Every city, in its specificities, in its transformations and in its thousand declinations offers itself to the eye of the reader as a system rich in connections, which over time has been consolidated starting from some places full of meaning in its historical memory, by virtue of the activities that took place in it.

Physical connections such as the network of paths, but also intangible connections that relate architectures and urban parts within invisible paths are associated. These connections are associated by historical periods, by typology, by function and implicitly defining an articulated system of places that gravitate around them and of paths that connect them.

Studying a city through the analysis of these places means preparing a critical reading, investigating the urban fabric as a system of physically or virtually interconnected events. The historic cities have developed around some presences, still strongly rooted in the collective memory, which have assumed a broader cultural role over the time.

Within this sphere of reflections, the present study intends to investigate the role of some 'elements' of urban furniture: The fountains. With particular reference to the fountains of the city of Salerno. Fountains intended both as elements that mark an urban void through their presence and to consecrate the place where they are placed as a meeting place, on the other implicitly suggesting the existence of a wider network present in the city itself and which correlates contexts analogues.

Fountains are sources of life. They are stories, they are intertwining, they are poles of attraction and place of relationships and the water that flows from them can be understood as a generative factor in the use of the space in which the fountain itself is located.

Since ancient times, water has been one of the main elements of life. It is origin and medium. Populate myth, religion and philosophy. Panta rei, everything flows, said Heraclitus, you cannot enter the same river twice.

Different peoples and civilizations have come into contact due to the ability of water to travel through places and to be a way of communication. Water does not have a shape, but adapts itself to what implicitly contains connections and establishing relationships of different kinds.

\section{The water and the city}

Once the fountains represented the meeting point of public life and before the creation of water networks, they were used by the inhabitants to supply water for daily consumption and for domestic use.

In the most important inhabited centres, alongside practical utility, an increasingly complex aesthetic requirement has also been developing in parallel. Over time, the fountains have therefore become elements of urban decor, embellishing the squares and city streets with statues, friezes and water features. With the arrival of water in the houses, the fountains lost their original purpose, but they still remain rooted in the memory of the places and, although they do not have the same importance they had at the time of their construction. They have retained an important role for their architectural, artistic and decorative value and for being an integral part of the urban reservoirs within which they are located and to which they give a strong identity value. The study of fountains cannot disregard the study of the urban context in which they are placed, as they are 'architectural episodes' that create a space. These elements strongly mark the shape, life and use of urban parts and therefore have a specific value with respect to the context in which they are placed. The fountains in fact establish an emotional relationship with the inhabitants of the city, a relationship that arises from the primordial bond with an essential asset, but also from the recognition of their aesthetic value.

The fountains over the centuries acquire an important architectural and sculptural value, assuming the role of elements of street furniture.

The fountains show themselves as real works of art that give identity and recognition to places where water becomes an aesthetic and expressive sign, animating the squares and decorating the urban scene. 
Fig. I. Location of the fountains in the historic centre of Salerno.

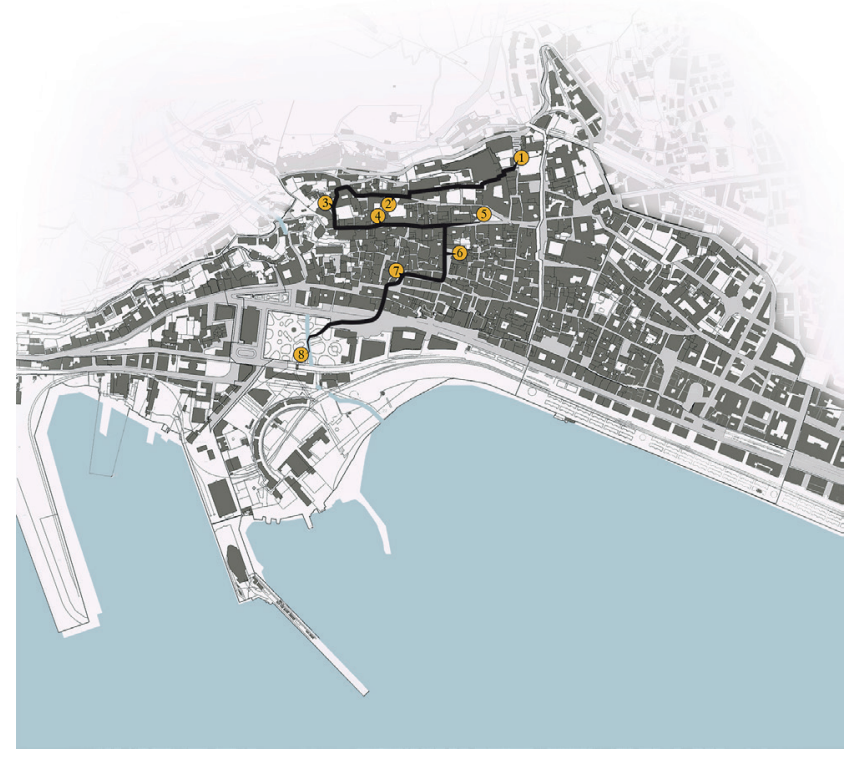

\section{The water and the city of Salerno}

Some cities have made their connection with water their strength and wealth. Salerno is one of the cities that most expresses this profound relationship and which, for this reason, has been chosen to tell the close relationship between city and water. Salerno was born and developed in an enchanting position, between the hills, the plain, the gulf and the sea. It is a city rich in contrasts, colors and disparate vegetation, testifying to the great abundance of water and canals that run through it. The landscape has changed a lot over the centuries, due to urbanization and housing demand, but it has never lost its synergy with the sea and the mountains in the background. [Vicidomini 2005]. Walking among the noble palaces, between the convents and the churches you will notice many details that embellish it. Salerno manages to have its own character from any point you look at it and the Arechi castle, the Minerva garden, the Verdi theater and the sea form a scenographic backdrop to the city. There are many signs of a strong and rooted past that has survived urbanization. Modern buildings and contaminations have not lost the link with the ancient city and the numerous finds along the streets of the city testify to its history. Salerno can be defined as a "city of water" because it is an urban settlement with a complex structure that maintains a strong relationship with water in its various forms. The fountains are an added value that plays a decisive role on the visual fruition of different urban areas [Bruttomesso 1993] (fig. I).

\section{The fountains of the historic centre of Salerno}

The study intends to prepare a cataloguing of the fountains of Salerno starting from some constituent elements identified in the design of the various examples (fig. 2).

A route is proposed to discover the most important and significant fountains of the historic centre starting from the top and descending towards the sea, following the trend of the level curves and thus favouring the flow of the waters of the canals towards the sea.

This "water path" connects eight different fountains built in different eras and of different workmanship, but all with a strong architectural value. For this reason, they have been studied, analysed and mapped in their main characteristics (fig. 3).

The fountains are a focal point of all the environments in which they are located and involve and determine the space in games of movement and light.

The itinerary begins with a private fountain, located in the garden of the Regional Administrative Court (TAR), the numerous alterations it has undergone have changed a lot of the 
Fig. 2. Connective path of the fountains of the historic centre of Salerno.
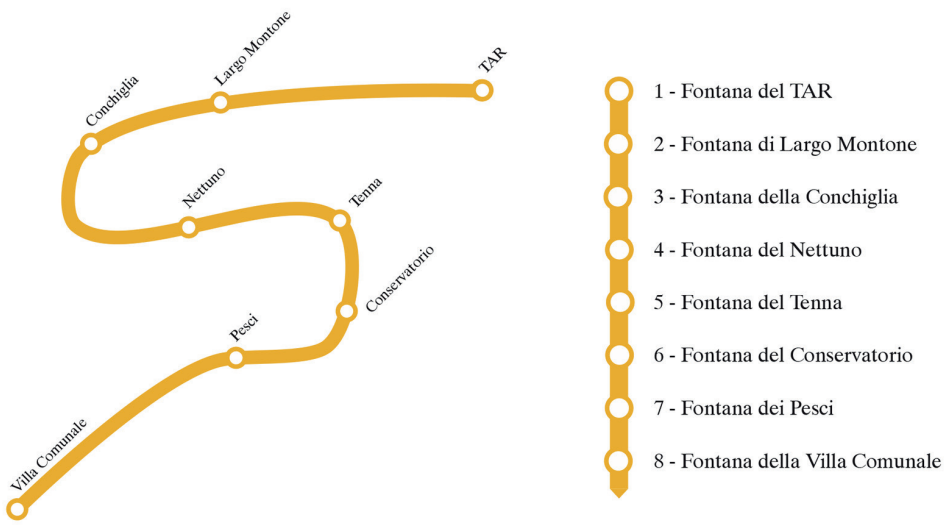

original appearance of the fountain and of the context in which it is located. The fountain is simple and harmonious, enclosed in a niche framed by pilasters. The water flowed through small cascades into a shell, and then ended up in the large polylobate basin. However, it is not active, despite the restorations at the end of the last century [De Martino 1997].

The next fountain is public, active and located in Largo Montone. Dating from around the seventeenth century, it is characterized by a single gush that emerges from the mouth of a mask with garlands. Continuing at the same altitude, we meet the "Seashell Fountain" which has become the symbolic image of the Minerva garden on an international level.

It was created in the fourteenth century, but the current monumental dimensions are the result of an expansion and restorations that took place in the seventeenth and eighteenth centuries. The fountain can be crossed, has a shell-shaped niche and is divided into three sections, with two enveloping pilasters on either side of the central basin.

Many palaces in the historic centre had private fountains to ensure supplies, but also to emphasize the power of the family. Palazzo Ruggi with the Neptune fountain inside its private courtyard is an important example. This fountain is very elaborate and with an antique flavour, but it was built in the 20th century and has not been active for many years.

Following the slope of the road, you reach piazza Abate Conforti. Opposite the monumental Church of the Santissima Addolorata stands the Tenna fountain on three steps. On the edges of the basin, four dolphins are symmetrically arranged from whose mouth water gushes. In the center of the basin there is a metal cup, probably a baptismal font.

Going down towards the sea you will find the Ave Gratia Plena Conservatory. Inside the courtyard leaning against the portico is a fountain with a strong visual impact, consisting of a niche flanked by pilasters with a capital. The construction culminates with a broken pediment and the water meets inside a curvilinear basin.

Some fountains are simpler and alternate with more complex ones, but they often maintain historical or stylistic ties between them. Some elements of the poetics of the Rococo period linked to great interpreters such as LuigiVanvitelli are very frequent. In fact, the next fountain is attributed to him, the famous 'Fishes Fountain' located in Largo Campo, and his expression is recognizable in a series of stylistic choices and elements that are also repeated in the other fountains he designed, located in various cities of Italy. It has a very strong impact because it is located in a Largo reachable by many important roads and gives strength to the views making them powerful and interesting. It is a highly iconic symbol of the entire historic centre and has undergone many changes and alterations over the centuries. It is configured as a rounded tub placed on two steps, the facade has a trapezoidal shape and is symmetrical. The central niche with the shell is framed by ashlar pilasters that support a wall on which four vases are placed. The jets of water flow from the central marble basin, from the metal fish placed on the edge of the basin and from the two masks with garlands. All these artistic elements create a small corner of history and art. A corner that links the different fountains of the city together and enriches it with beauty.

The itinerary ends by descending further and further towards the sea and passing through the Villa Comunale. The Tullio Fountain is in Baroque style, and at first it housed a statue 

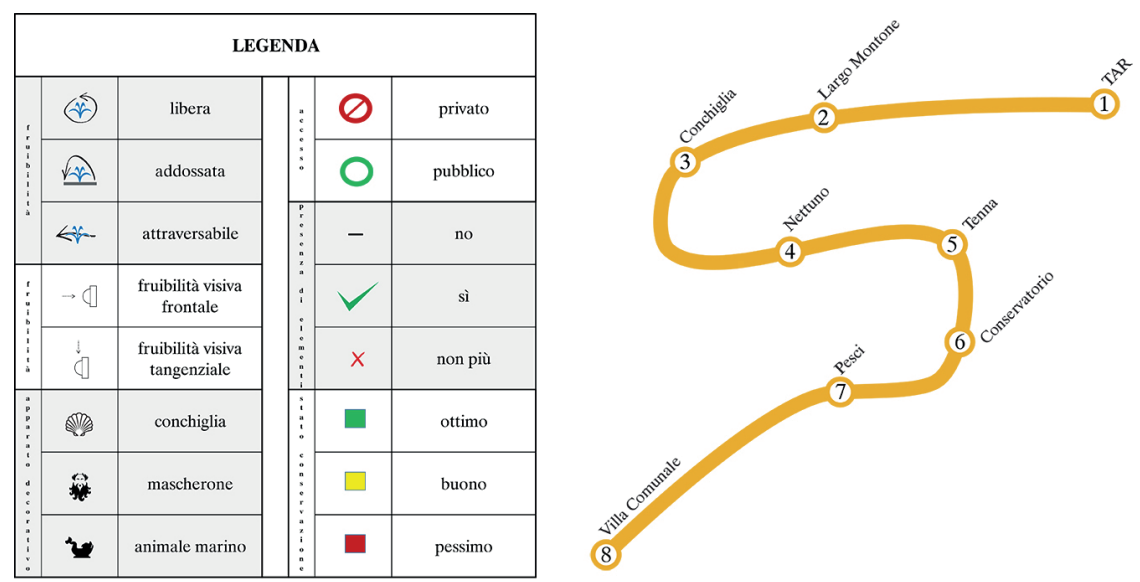

\begin{tabular}{|c|c|c|c|c|c|c|c|c|}
\hline numero & ) & 2 & 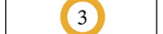 & ) & 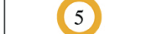 & & & 3) \\
\hline nome & Fontana del TAR & $\begin{array}{c}\text { Fontana di Largo } \\
\text { Montone }\end{array}$ & $\begin{array}{c}\text { Fotana della } \\
\text { Conchiglia }\end{array}$ & $\begin{array}{c}\text { Fontana del } \\
\text { Nettuno }\end{array}$ & Fontana del Tenna & $\begin{array}{c}\text { Fontana del } \\
\text { Conservatorio Ave } \\
\text { Gratia Plena }\end{array}$ & Fontana dei Pesci & Fontana del Tullio \\
\hline \multicolumn{9}{|l|}{ ortofoto prospetto } \\
\hline indirizzo & \begin{tabular}{|c|} 
Tribunale \\
Amministrativo \\
Regionale, Largo San \\
Tommaso D'Aquino
\end{tabular} & Largo Montone & $\begin{array}{c}\text { Giardino della } \\
\text { Minerva, Vicolo } \\
\text { Ferrante Sanseverino }\end{array}$ & $\begin{array}{l}\text { Palazzo Ruggi, Via } \\
\text { Tasso }\end{array}$ & Piazza Abate Conforti & Via dei Canali & Largo Campo & $\begin{array}{c}\text { Giardini della Villa } \\
\text { Comunale, Via } \\
\text { Gaetano D'Agostino }\end{array}$ \\
\hline periodo & XVII sec & XIV sec & XIV secolo & $\mathrm{XX} \sec$ & XVII sec & XVIII sec & XVII sec & XVIII \\
\hline ubicazione & corte interna & largo & terrazzo panoramico & corte interna & piazza & corte interna & largo & piazza \\
\hline impatto visivo & $\rightarrow \square$ & ¿ & $\rightarrow D$ & $\square$ & $\rightarrow O$ & $\rightarrow \subset$ & & $\rightarrow D^{2}=$ \\
\hline fruibilità & $\leftrightarrow$ & (*) & « & (x) & (ब) & (v) & x & (ब) \\
\hline $\begin{array}{l}\text { apparato } \\
\text { decorativo }\end{array}$ & 急 & 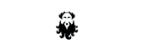 & 8 & - & 3 & - & 30 & - \\
\hline accesso & $\varnothing$ & 0 & $\varnothing$ & $\varnothing$ & 0 & $\varnothing$ & & 0 \\
\hline in attività & $x$ & & $\checkmark$ & $x$ & & & & \\
\hline $\begin{array}{c}\text { stato di } \\
\text { conservazione }\end{array}$ & $\square$ & $\square$ & $\square$ & $\mathbf{\square}$ & $\square$ & $\square$ & $\square$ & $\square$ \\
\hline $\begin{array}{l}\text { presenza partito } \\
\text { architettonico }\end{array}$ & $\checkmark$ & 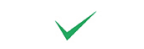 & $\checkmark$ & - & - & $V$ & & \\
\hline $\begin{array}{l}\text { presenza elementi } \\
\text { scultorei }\end{array}$ & - & - & - & $\checkmark$ & - & - & - & $x$ \\
\hline
\end{tabular}

which was then stolen. It is currently active and enriches the landscape connection between the Verdi Theatre, the sea and the ancient historic city. it has great scenic importance, which enhances and is enhanced by the context and the whole in which it is located (fig. 4).

\section{Survey and drawing as an expressive means of communication}

The growing interest in the documentation and enhancement of the architectural heritage present in the historic centers of the cities has focused attention on the methodologies and technologies useful for the survey. Technology thus becomes at the service of knowledge and representation becomes a useful means for communication and dissemination.

The technological development of photogrammetry software has encouraged many major campaigns with the possibility of creating 3D models and of investigating and navigating the model obtained by exploring its specificities. The drafting of a good architectural survey is fundamental and at the basis of all stages of knowledge of a work. It is the result of an initial 

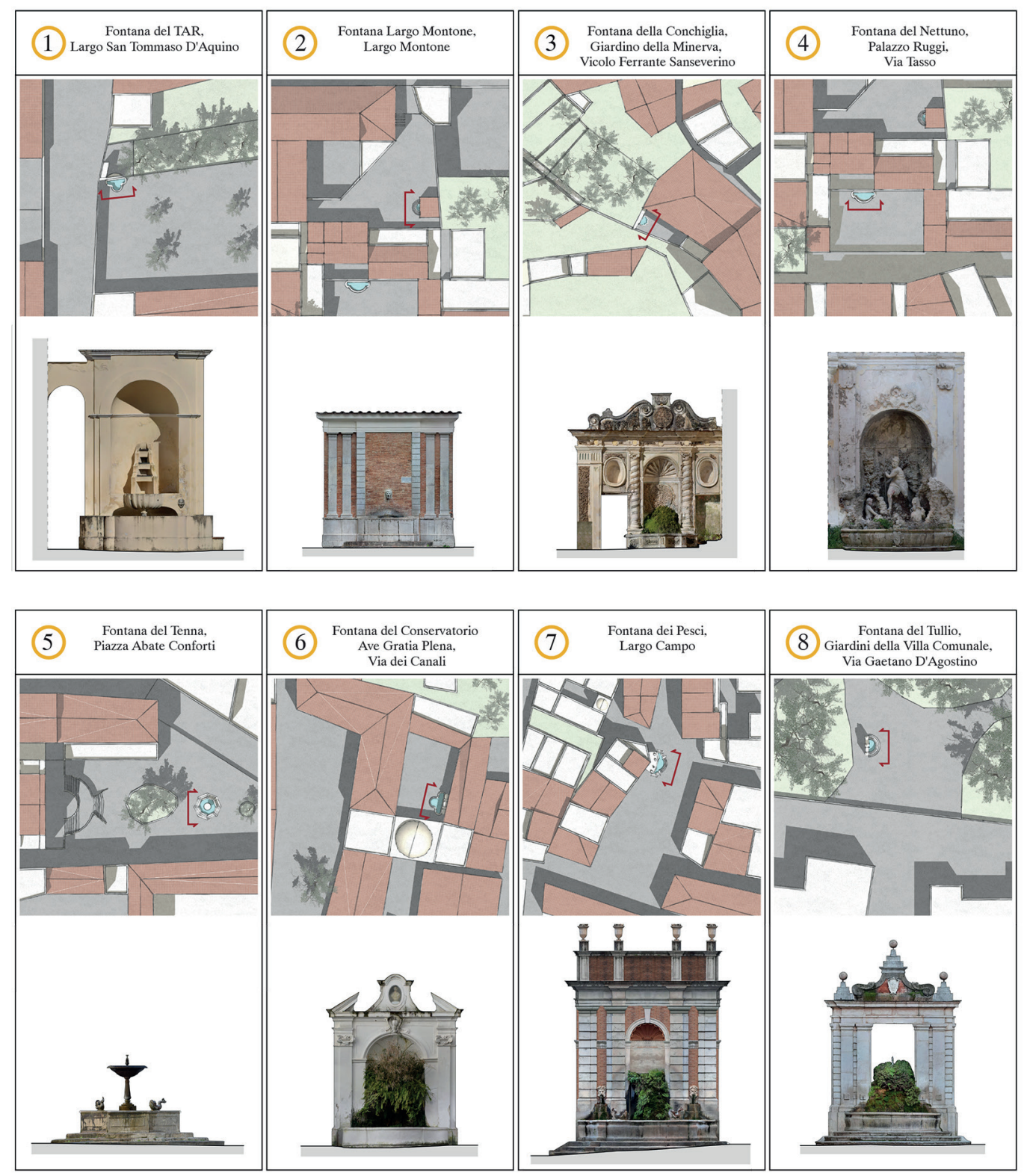

Fontana del Tullio,
Giardini della Villa Comunale,
Via Gaetano D'Agostino

Fig. 4. Planimetric excerpts of the context and elevations of the respective fountains.

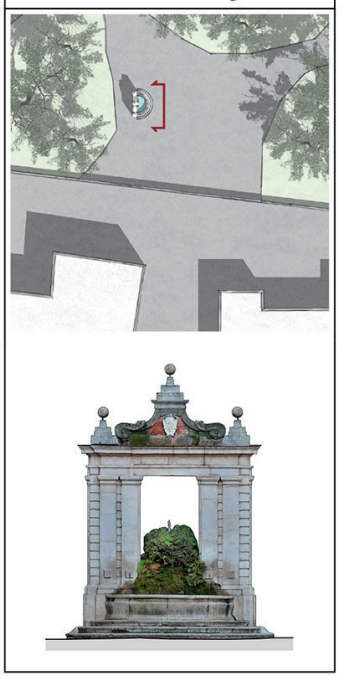

1

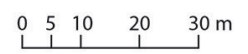

Scala metrica prospetto

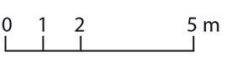

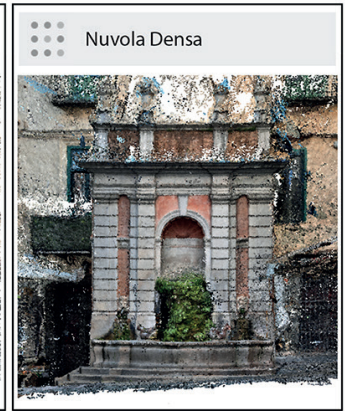
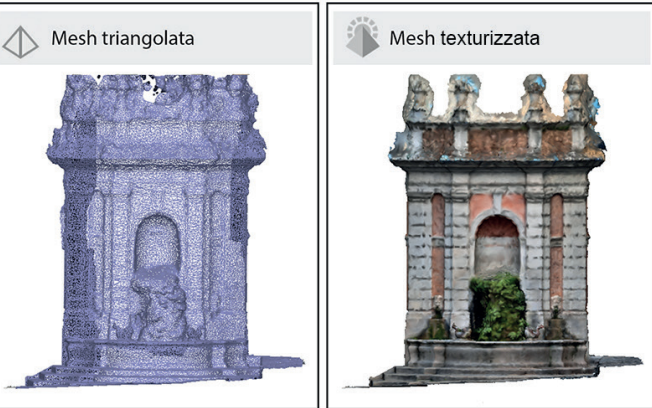

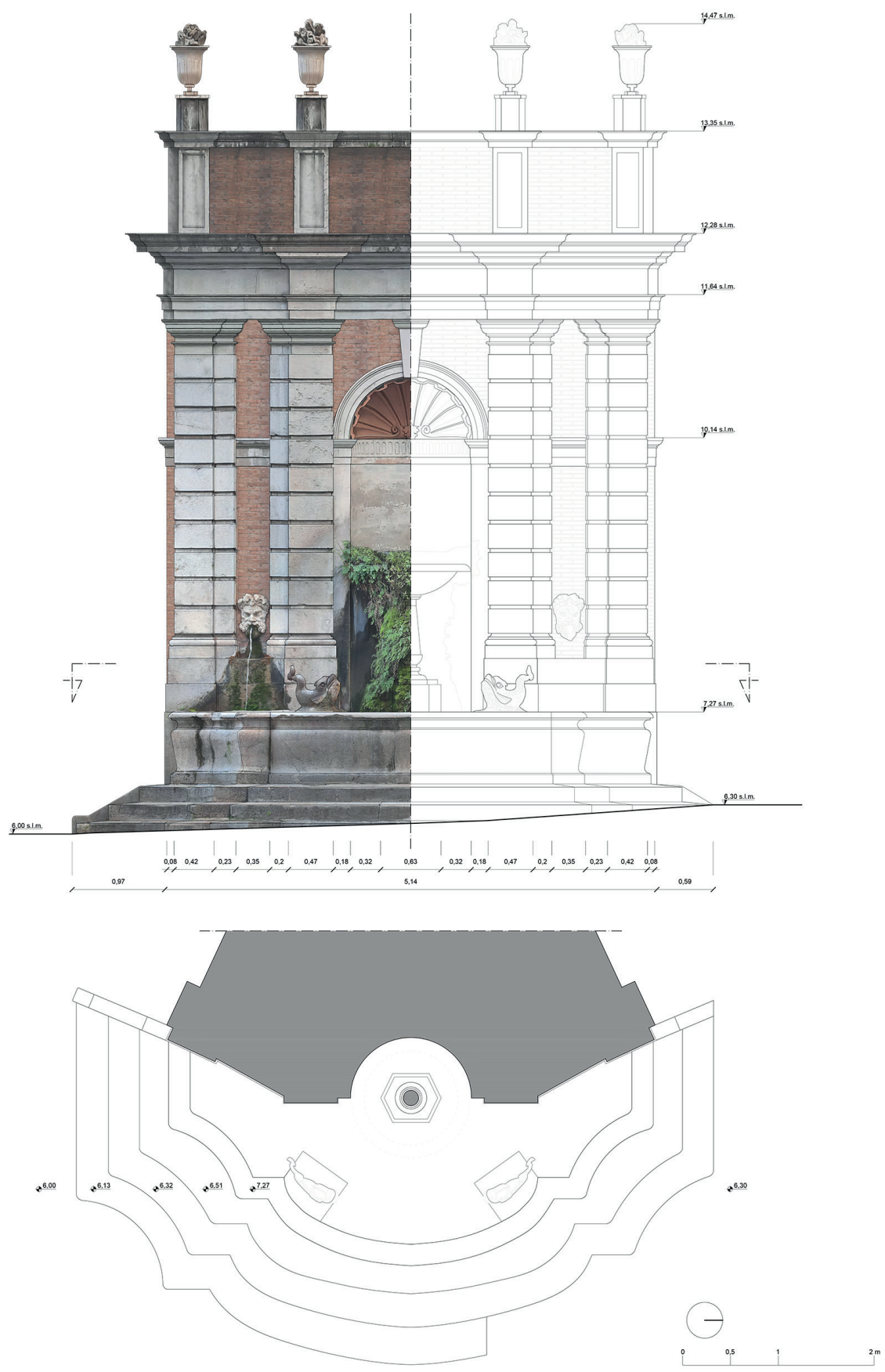

understanding of the criticism of the object and all the phases that follow derive from a process of study and interpretation in all its constitutive aspects.

Through the survey, it is possible to investigate the qualities of each artefact in reality, deepening its morphological and dimensional data. Alongside this, representation, in its aptitude for documenting, makes it possible to study these relationships by placing the various examples on a single level of representation. Thus, each element acquires a new meaning in the comparison with the others and in the synoptic reading that derives from it and highlights all its intrinsic values in relation to the urban context. The survey and the drawing are therefore always the result of a critical process and for this reason, it is also important to choose the most suitable methodology according to the case being examined. To detect "punctual" objects such as fountains, the best choice was to use a Nikon D3300 Reflex Camera for photogrammetric survey. 
The photos were taken with parallel axis and converging axis taken with an overlap of at least $80 \%$ vertically and horizontally. The alignment of the different high-quality shots (about 350 shots for each fountain) led to the creation of sparse and then dense point clouds.

Each point cloud was cleaned of all disturbing elements and external to the object and then a 3D mesh has been generated from these (fig. 5).

The absolute coordinates were not known and therefore markers were placed above and near the fountains. Within the Metashape program, the different distances of the markers were entered in the scale bar, and it was possible to obtain a scaled but not geo-referenced model. The error for each fountain is about I- $2 \mathrm{~mm}$. From each model obtained, it was possible to extrapolate ortho-photos of the different fronts, useful for the elaboration of the relative elevations and sections (fig. 6).

\section{Conclusions}

Each city is the sum of single elements, stories and passages that have connected and evolved between them. It is not possible to know a city without knowing its various components and how they relate. The more the object has been analyzed and studied in its entirety, the greater the amount of information that the observer will be able to acquire.

Each survey will therefore be the result of a choice, an operation of critical synthesis and each drawing, in addition to being metrically accurate, will highlight the formal characteristics, the material, the state of conservation and the relationship of the various elements.

The survey and the drawing are therefore essential tools for those who will have to understand the nature and history of a certain artefact or for those who cannot see it in person will still be aware of it and will be able to enjoy the architecture in its physicality and complexity even without being directly on site.

In this pandemic period, where segregation has reduced our ability to relate to others and visit cities, 3D representations and their ease of reading are the main tool for the study and development of innovation. All aimed at improving knowledge, accessibility and use of heritage within the cities.

\section{References}

AA.W. ( 1997). Fontane in città. $12^{a}$ Settimana dei beni culturali «l luoghi del patrimonio». Salerno: Menabò Comunicazione.

AA.V. (2005). Visitiamo la città. Ciclo di visite guidate 2004-2005. Salerno: Assessorato Al Turismo.

Bruttomesso R. (1993). Waterfronts. A new frontier for cities on water. Venezia: Centro internazionale città d'acqua.

De Luca L. (20I I). La fotomodellazione architettonica. Rilievo, modellazione, rappresentazione di edifici a partire da fotografie. Palermo: Flaccovio.

Docci M., Maestri D. (2009). Manuale di rilevamento architettonico e urbano. Milano: Laterza.

Falda G.B., De Rossi G.G., Venturini G.F. ( 684). Le fontane di Roma nelle piazze, e luoghi publici della città, con li loro prospetti, come sono al presente. Roma: ETH-Bibliothek Zürich.

Ferrari L. (2004). Acqua che ri-corre nei luoghi. In Ri-Vista. Ricerche per la progettazione del paesaggio. n. I, vol. 2.

Lauretano M. (1997). Salerno e il suo centro storico. Salerno: Poligraf.

Remondino F. (20 I I). Rilievo e modellazione 3D di siti e architetture complesse. In Disegnarecon. n.4, vol. 8, pp. 90-98.

Author

Mara Gallo, Università degli Studi di Napoli Federico II, mara.gallo@unina.it

To cite this chapter. Gallo Mara (2021). Le 'fonti' delle connessioni/The 'Sources' of Connections. In Arena A., Arena M., Mediati D., Raffa P. (a cura di). Connettere. Un disegno per annodare e tessere. Linguaggi Distanze Tecnologie. Atti del $42^{\circ}$ Convegno Internazionale dei Docenti delle Discipline della Rappresentazione/Connecting. Drawing for weaving relationship. Languages Distances Technologies. Proceedings of the 42th International Conference of Representation Disciplines Teachers. Milano: FrancoAngeli, pp. 2337-2352. 